US Army Corps

of Engineers

Waterways Experiment

Station

\title{
Surface Wind Analyses and Storm-Surge Effects of Hurricane Emily on the Outer Banks of North Carolina
}

\author{
by Andrew W. Garcia
}

Approved For Public Release; Distribution Is Unlimited

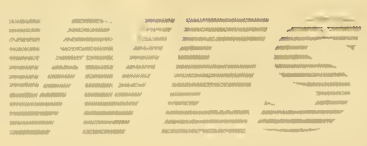


The contents of this report are not to be used for advertising, publication, or promotional purposes. Citation of trade names does not constitute an official endorsement or approval of the use of such commercial products. 


\section{Surface Wind Analyses and Storm-Surge Effects of Hurricane Emily on the Outer Banks of North Carolina}

by Andrew W. Garcia

U.S. Army Corps of Engineers

Waterways Experiment Station

3909 Halls Ferry Road

Vicksburg, MS 39180-6199

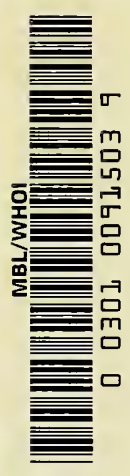

Final report

Approved for public release; distribution is unlimited 


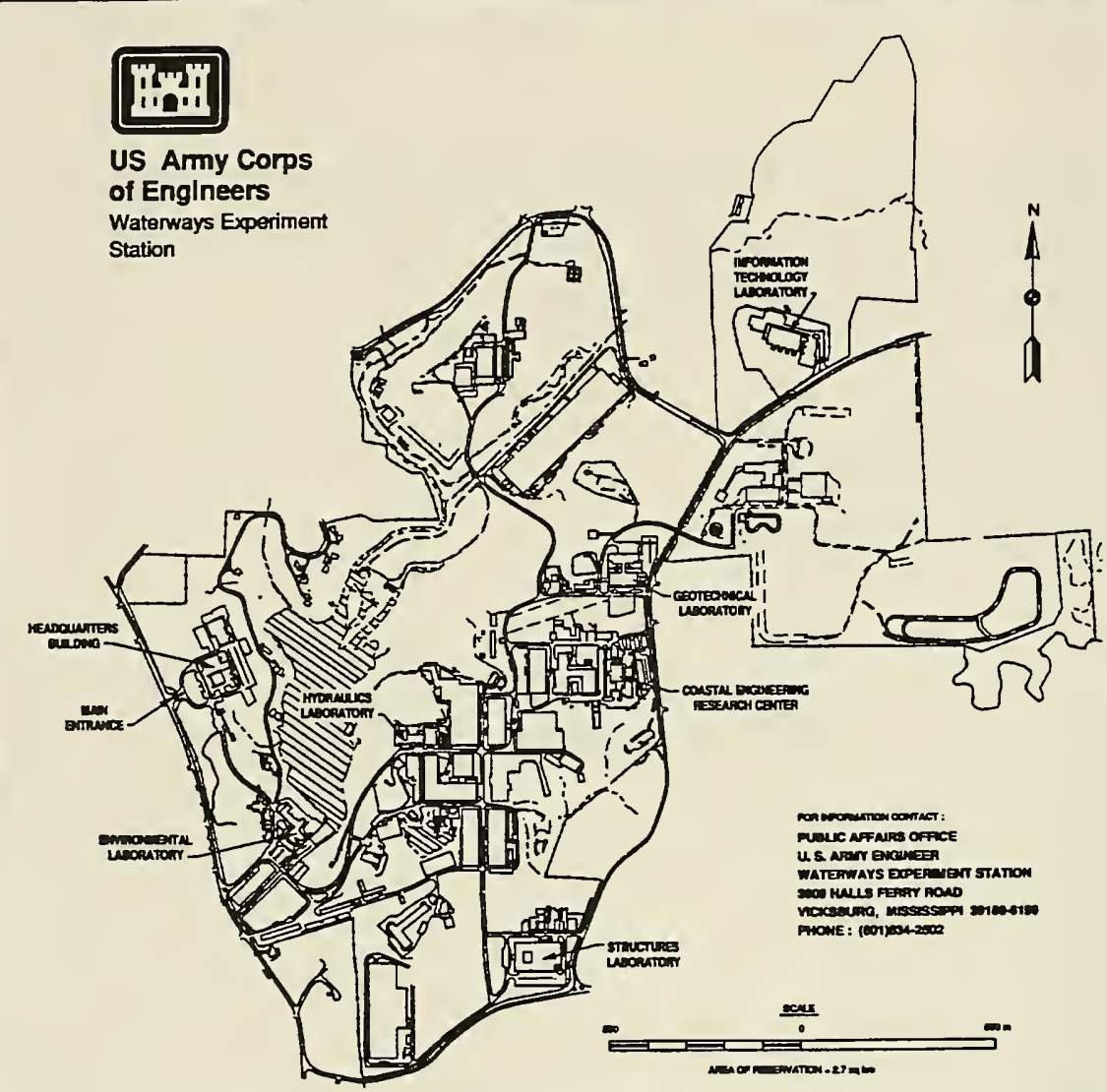

Waterways Experiment Station Cataloging-in-Publication Data

Garcia, Andrew W.

Surface wind analyses and storm-surge effects of Hurricane Emily on the Outer Banks of North Carolina / by Andrew W. Garcia ; prepared for U.S. Army Corps of Engineers.

24 p. : ill. ; $28 \mathrm{~cm}$. - (Miscellaneous paper ; CERC-95-9) Includes bibliographic references.

1. Hurricane Emily, 1993. 2. Storm surges. 3. Storm winds. I. United States. Army. Corps of Engineers. II. U.S. Army Engineer Waterways Experiment Station. III. Coastal Engineering Research Center (U.S. Army Engineer Waterways Experiment Station) IV. Title. V. Series: Miscellaneous paper (U.S. Army Engineer Waterways Experiment Station) ; CERC-95-9. 


\section{Contents}

Preface $\ldots \ldots \ldots \ldots \ldots \ldots \ldots \ldots \ldots \ldots \ldots \ldots \ldots \ldots \ldots \ldots$ iv

Conversion Factors, Non-SI to SI Units of Measurement $\ldots \ldots \ldots \ldots \ldots v$

1 -Introduction $\ldots \ldots \ldots \ldots \ldots \ldots \ldots \ldots \ldots \ldots \ldots \ldots \ldots \ldots \ldots$

2-Surface Wind Analyses ..................... 4

3-Storm Surge Characteristics and Effects $\ldots \ldots \ldots \ldots \ldots \ldots, 9$

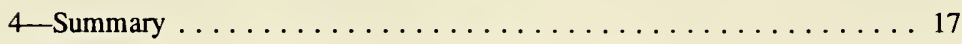

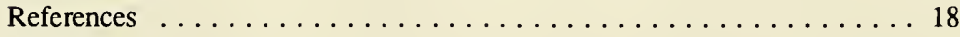

SF 298 


\section{Preface}

The work described herein was authorized by Headquarters, U.S. Army Corps of Engineers (HQUSACE). The work was performed under the Episodic Events Work Unit 12112 of the Coastal Field Data Collection Program at the Coastal Engineering Research Center (CERC), U.S. Army Engineer Waterways Experiment Station (WES). Messrs. John H. Lockhart, Jr., Charles B. Chesnutt, and Barry W. Holliday were HQUSACE Technical Monitors. Ms. Carolyn M. Holmes, CERC, was Program Manager of the Coastal Field Data Collection Program.

This study was performed by Dr. Andrew W. Garcia, Prototype Measurement and Analysis Branch (PMAB), Engineering Development Division (EDD), during the period September 1993 to March 1995. This report was prepared by Dr. Garcia. This study was performed under the administrative supervision of Dr. James R. Houston, Director, CERC; Mr. Charles C. Calhoun, Assistant Director, CERC; Mr. Thomas W. Richardson, Chief, EED; and Mr. William L. Preslan, Chief, PMAB.

At the time of publication of this report, Director of WES was Dr. Robert W. Whalin. Commander was COL Bruce K. Howard, EN.

The contents of this report are not to be used for advertising, publication, or promotional purposes. Citation of trade names does not constitule an official endorsement or approval of the use of such commercial products. 


\section{Conversion Factors, Non-SI to SI Units of Measurement}

Non SI-units of measurement used in this report can be converted to SI units as follows:

\begin{tabular}{||l|l|l|}
\hline Multiply & By & To Obtain \\
\hline \hline feet & 0.3048 & meters \\
\hline knots (international) & 0.5144444 & meters per second \\
\hline miles (U.S. nautical) & 1.852 & kilometers \\
\hline miles (U.S. statute) & 1.609347 & kilometers \\
\hline
\end{tabular}





\section{Introduction}

The meteorological system which evolved into Hurricane Emily was detected on 22 August 1993 via satellite imagery as a cloud pattern typical of a tropical depression. At the time, it was located approximately 1,800 miles $^{1}$ southeast of Cape Hatteras, the point of closest approach to land in the continental United States. Emily persisted as a tropical depression for the next 2 days while moving to the northwest. On 25 August, Emily slowed to almost a stop and the system began to intensify, being upgraded to tropical storm status. Emily briefly attained minimal hurricane strength on 26 August as it began to move toward the southwest. During the next 2 days, Emily gradually turned again to the northwest and re-intensified, attaining Saffir-Simpson scale category 3 hurricane status on 31 August 1993. On 1 September 1993, Emily skirted the Outer Banks of North Carolina while on a northward track, then tumed toward the northeast and moved back into the Atlantic. Figure 1 (from Lawrence (1993)) shows the track of Emily.

The histories of Emily's central pressure and maximum wind speeds are shown in Figures 2 and 3 (from Lawrence (1993)). The maximum surface wind speed of slightly more than 100 knots was observed about the same time as was the minimum central pressure; both occurred at the time of closest approach to land. The radius of maximum winds at this time was approximately 23 miles (Lawrence 1993). The position of Emily's maximum winds relative to the Outer Banks during the storm's passage resulted in flood water being forced from Pamlico Sound across the barrier island into the Atlantic Ocean.

\footnotetext{
I A table of faclors for converting non-SI units of measurement to SI units is presented on page v.
} 


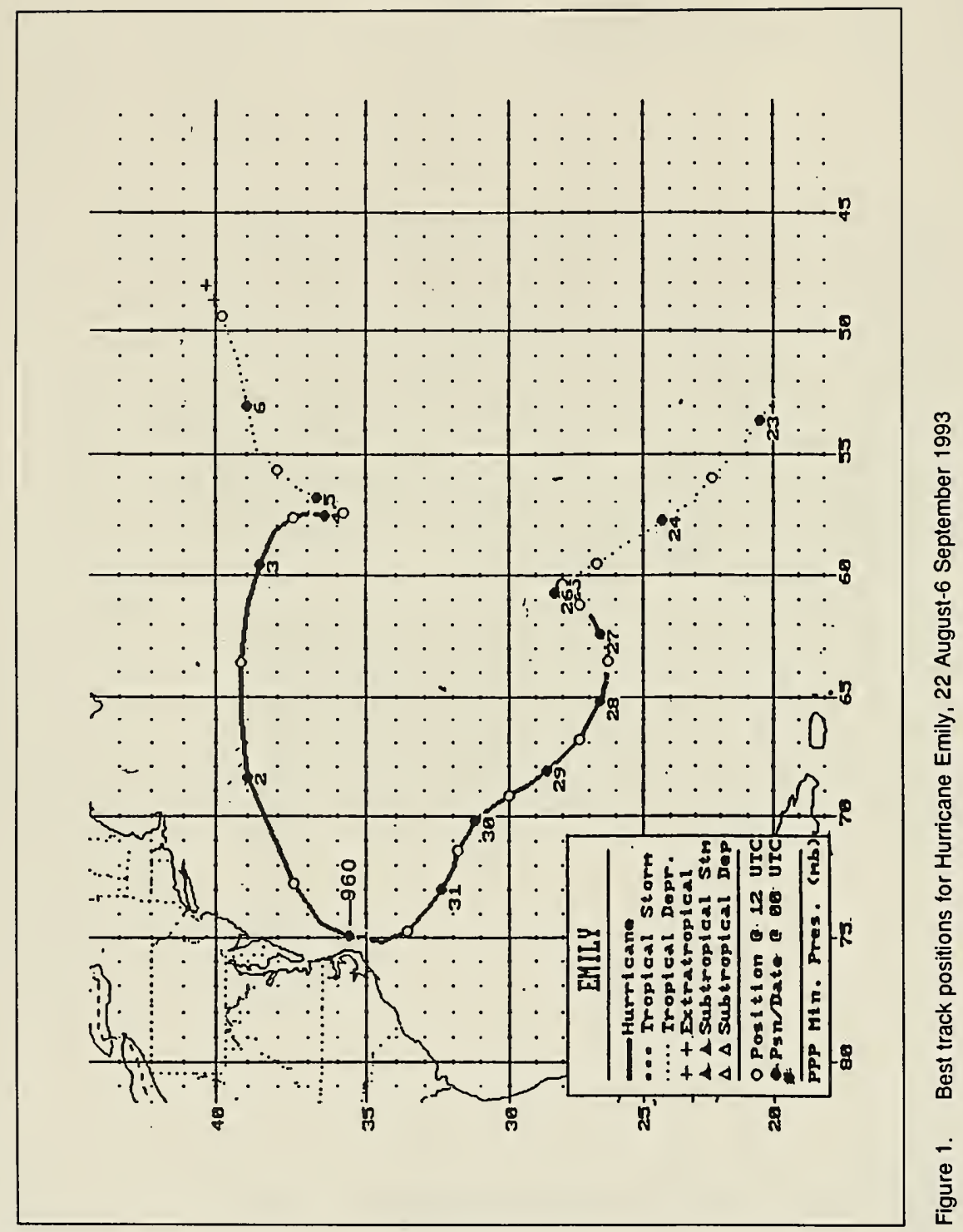




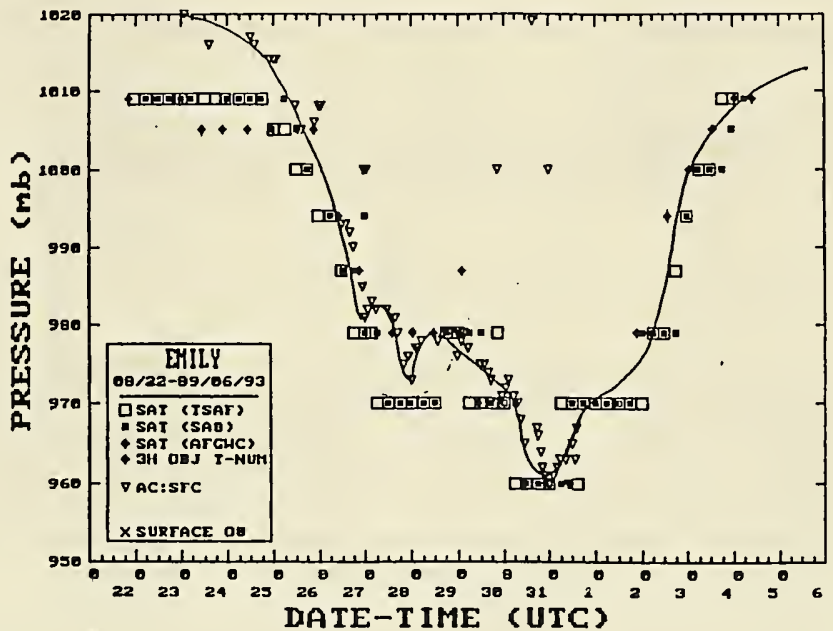

Figure 2. Best track minimum central pressure curve for Hurricane Emily

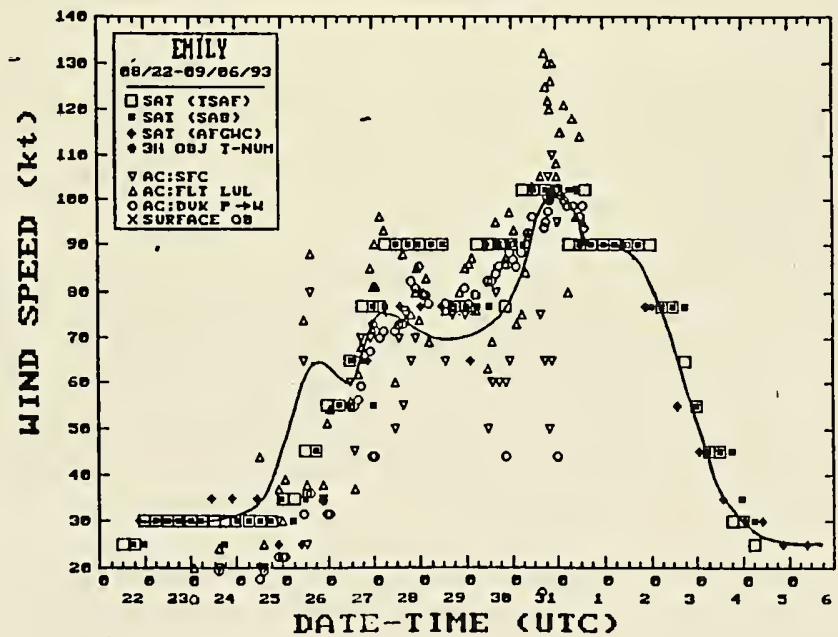

Figure 3. Best track 1-min sustained wind speed curve for Hurricane Emily 


\section{Surface Wind Analyses}

A series of surface wind analyses were prepared by the staff of the Hurricane Research Division, Atlantic Oceanographic and Meteorological Laboratory, National Oceanic and Atmospheric Administration. The analyses are based upon wind data acquired from a variety of sources including reconnaissance aircraft, moored buoys, coastal meteorological stations, and ship reports. A description of the analysis techniques used may be found in Powell, Dodge, and Black (1991) and Powell, Houston, and Reinhold (in preparation).

Three analyses were selected for inclusion in this report; $1400 \mathrm{hr}$ Coordinated Universal Time (UTC) 31 August, $2200 \mathrm{hr}$ UTC 31 August, and $0200 \mathrm{hr}$ UTC 1 September, 1993 (Figures 4, 5, and 6, respectively). These analyses were selected as depicting Emily's surface wind fields shortly before the point of closest approach to land (PCA), at the time of PCA, and just subsequent to PCA. The solid lines in these figures are streamlines indicating the wind direction. The dashed line are isotachs, i.e., contours of constant windspeed.

At $1400 \mathrm{hr}$ UTC on 31 August (Figure 4), the eye of Emily was approximately 130 miles from Cape Hatteras, with the dominant motion toward the north-northwest. Maximum surface winds were approximately 86 knots (Burpee et al. 1994). At the time, the dominant wind direction over Pamlico Sound was from the east-northeast at approximately 40 knots.

During the next $8 \mathrm{hr}$, Emily took a slightly more northerly course and moved to within about 15 miles of Cape Hatteras (Figure 5). The maximum winds at this time were slightly greater than 100 knots and the winds over Pamlico Sound had increased to between 70 and 90 knots. The wind directions over the Sound varied from north-northeast to south-southeast, depending upon location. It is apparent from the streamline depiction at this time that high surge levels would be expected to occur on the Pamlico Sound side of the Outer Banks south of Cape Hatteras.

By $0200 \mathrm{hr}$ UTC 1 September 1993, the center of Emily had moved to about $100 \mathrm{~km}$ northeast of Cape Hatteras (Figure 6) on a track that was continuing to tum more toward the east. Although the maximum sustained wind speed in Emily was still slightly in excess of 100 knots, the storm's movement away from Cape Hatteras had reduced the wind speeds over Pamlico Sound to between 30 and 70 knots with the direction predominantly from the northwest. 


\section{Hurricane Emily - Real-time Analysis 1400 UTC 31 Aug. 1993 \\ Maximum 1 min Sustained Surface Winds (kt)}

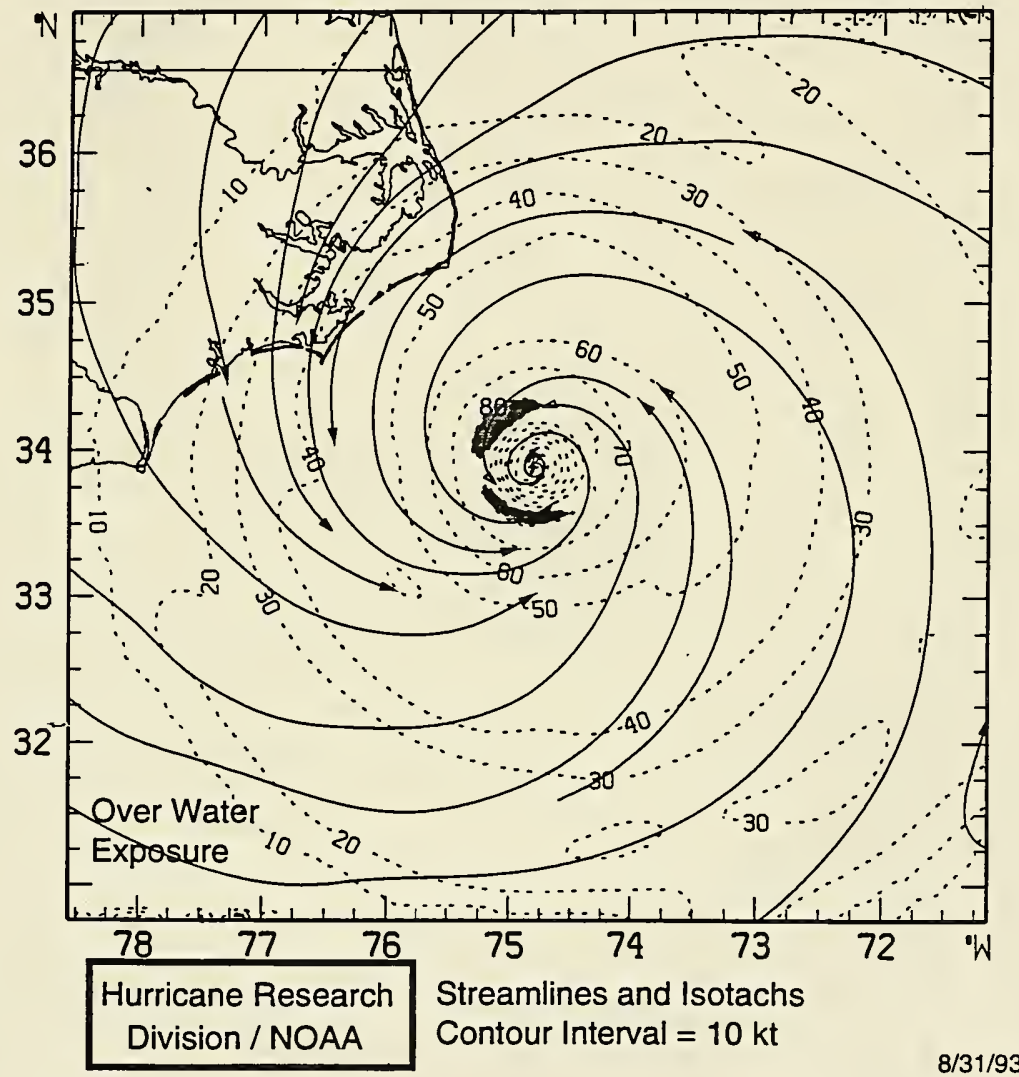

Figure 4. Surface wind analysis for Hurricane Emily $1400 \mathrm{hr}$ UTC 31 August 1993 


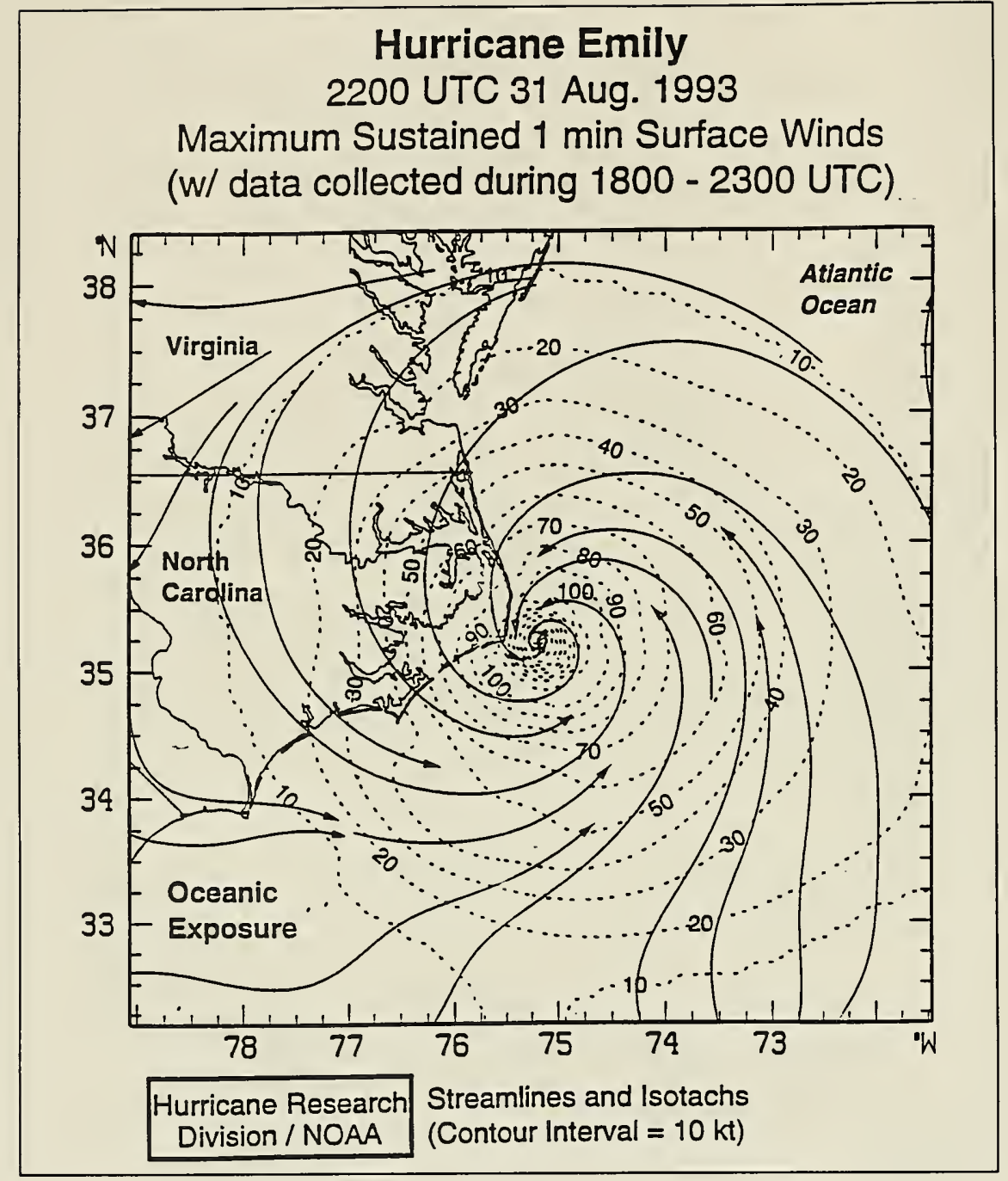

Figure 5. Surface wind analysis for Hurricane Emily 2200 hr UTC 31 August 1993 


\section{Hurricane Emily - Real-time Analysis 0200 UTC 1 September 1993}

Maximum 1 min Sustained Surface Winds (kt) (data collected during 2030 UTC 8/31 - 0200 UTC 9/1)

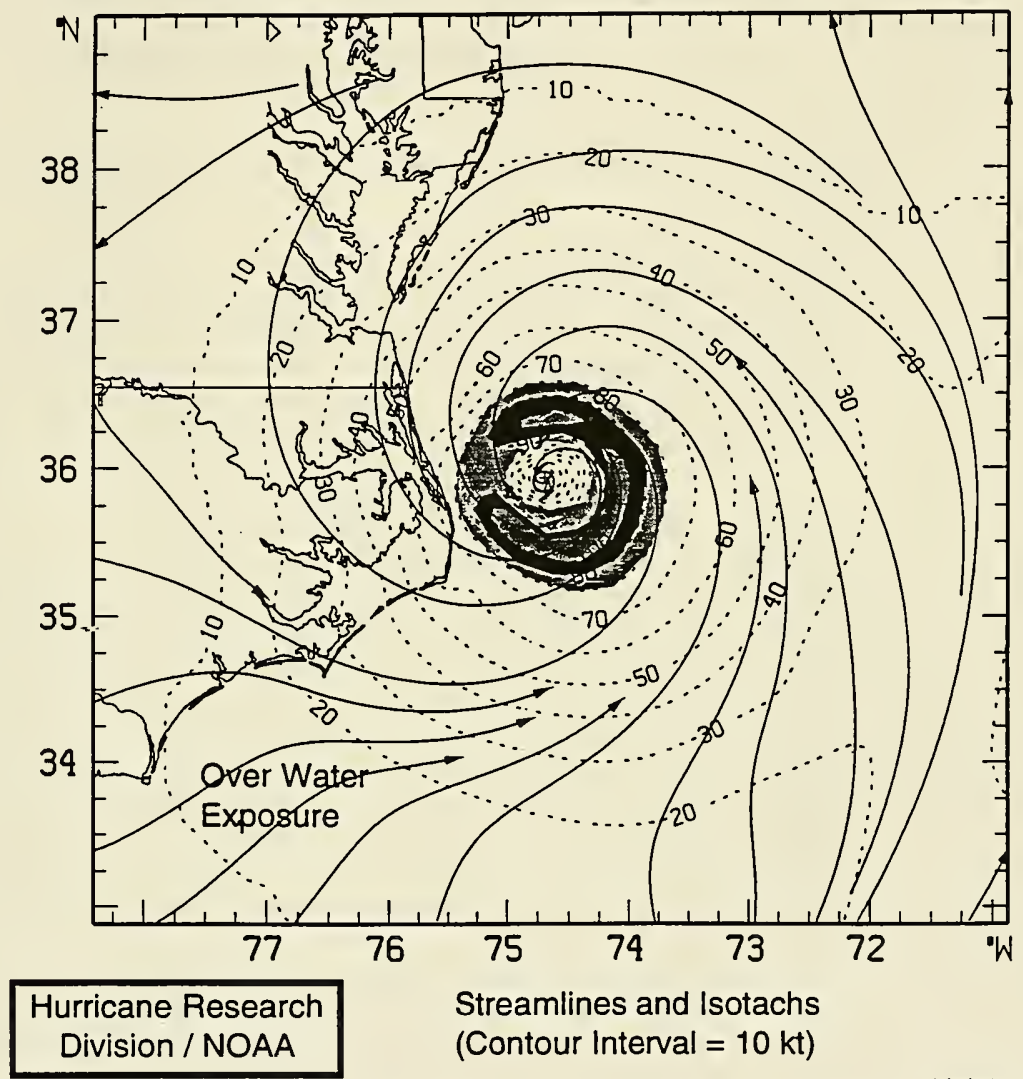

Figure 6. Surface wind analysis for Hurricane Emily $0200 \mathrm{hr}$ UTC 1 September 1993 
The streamline depiction over Pamlico Sound in Figure 6 suggests the dominant flow of water comprising the storm surge would have occurred along the back side of the barrier islands. Streamline depictions north of Cape Hatteras at this time are approximately parallel to the shoreline; therefore, one would expect relatively low surge levels along the oceanic coast. Characteristics of the storm surge are discussed in detail in Chapter 3. 


\section{Storm Surge Character- istics and Effects}

Reconnaissance of the affected area of the Outer Banks for evidence of storm surge inundation began on 1 September 1993. Field teams from the U.S. Geological Survey (USGS) office in Raleigh, NC, moved into the affected area to identify high water marks. The USGS effort was performed under a tasking from the Federal Emergency Management Agency (FEMA), with funding jointly provided by FEMA, the U.S. Army Corps of Engineers, and National Weather Service.

The USGS field teams identified 108 high-water marks on the Outer Banks between the communities of Avon and Hatteras (see Figure 7 for locations of communities). Of the 108 marks initially identified, 62 were selected as being of sufficient quality to adequately represent the elevation and extent of flooding. Each of the 62 selected marks was leveled using a total stations instrument referenced to a local benchmark network. Data for each of the marks were tabulated to show location referenced to latitude and longitude, type and quality of mark, and the water-level and ground surface elevations. Marks acquired inside structures are tabulated to the nearest hundredth foot, while outside marks and ground elevations are tabulated to the nearest tenth. These data are presented in Table 1; marks recovered inside structures are denoted as "I," and marks recovered outside are denoted as "O."

The northem extent of flooding along the Outer Banks barrier island occurred about 1 mile north of the Little Kinnakeet Coast Guard Station. To the north of Little Kinnakeet, the elevation of coastal Highway 12 increases, forming a barrier which confined the inundation to the narrow strip of land between the shore and highway.

To the south of Little Kinnakeet, the entire community of Avon was inundated except for isolated elevated areas. South of Avon, Highway 12 was inundated by water from the Pamlico Sound side of the barrier island, which was prevented from flowing into the Atlantic Ocean by the beach dunes at elevations higher than the highway. High-water marks acquired along this stretch of Highway 12 were between 7 and $9 \mathrm{ft}$ above National Geodetic Vertical Datum (NGVD). Water levels increased in elevation as one approached 


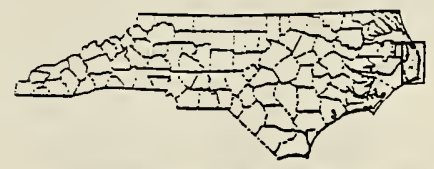

LOCATION OF STUDY AREA IN NORTH CAROLINA

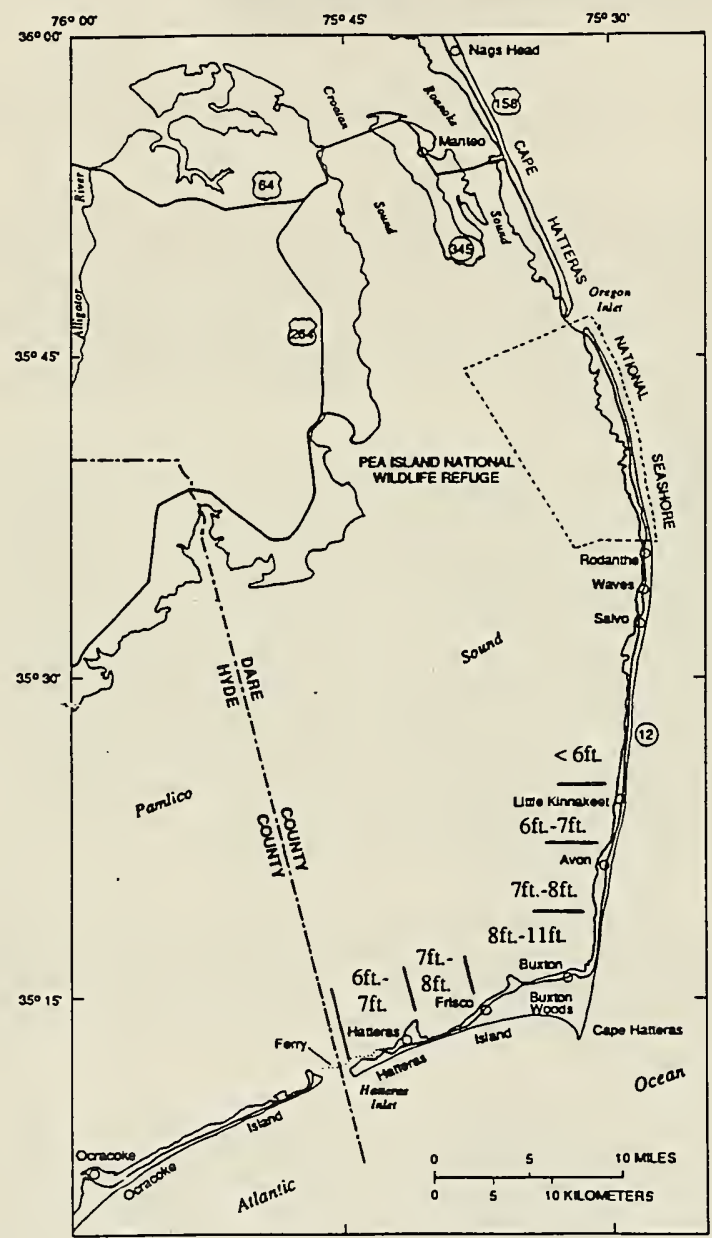

Figure 7. Areal distribution of high-water levels caused by Hurricane Emily on Cape Hatteras 


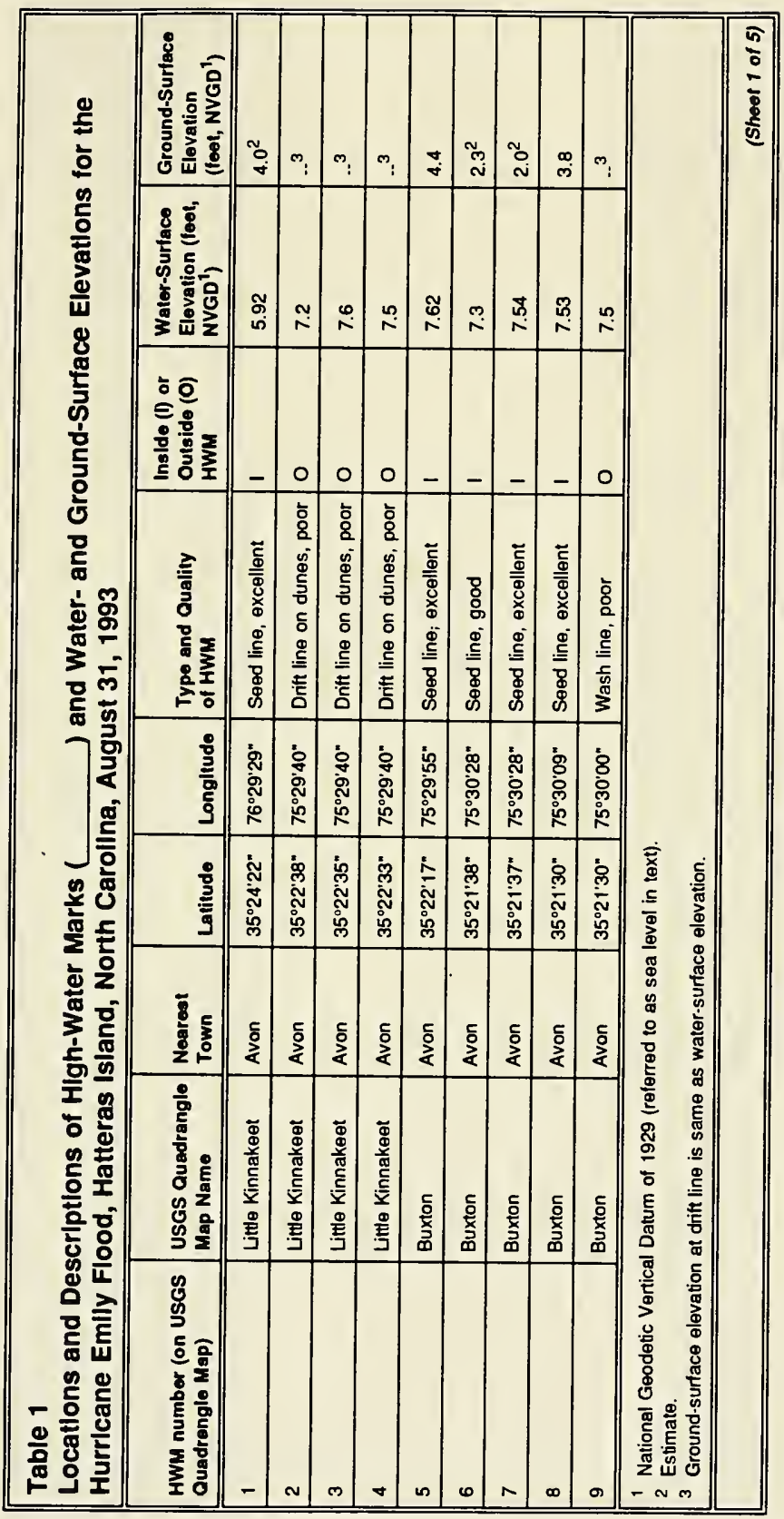




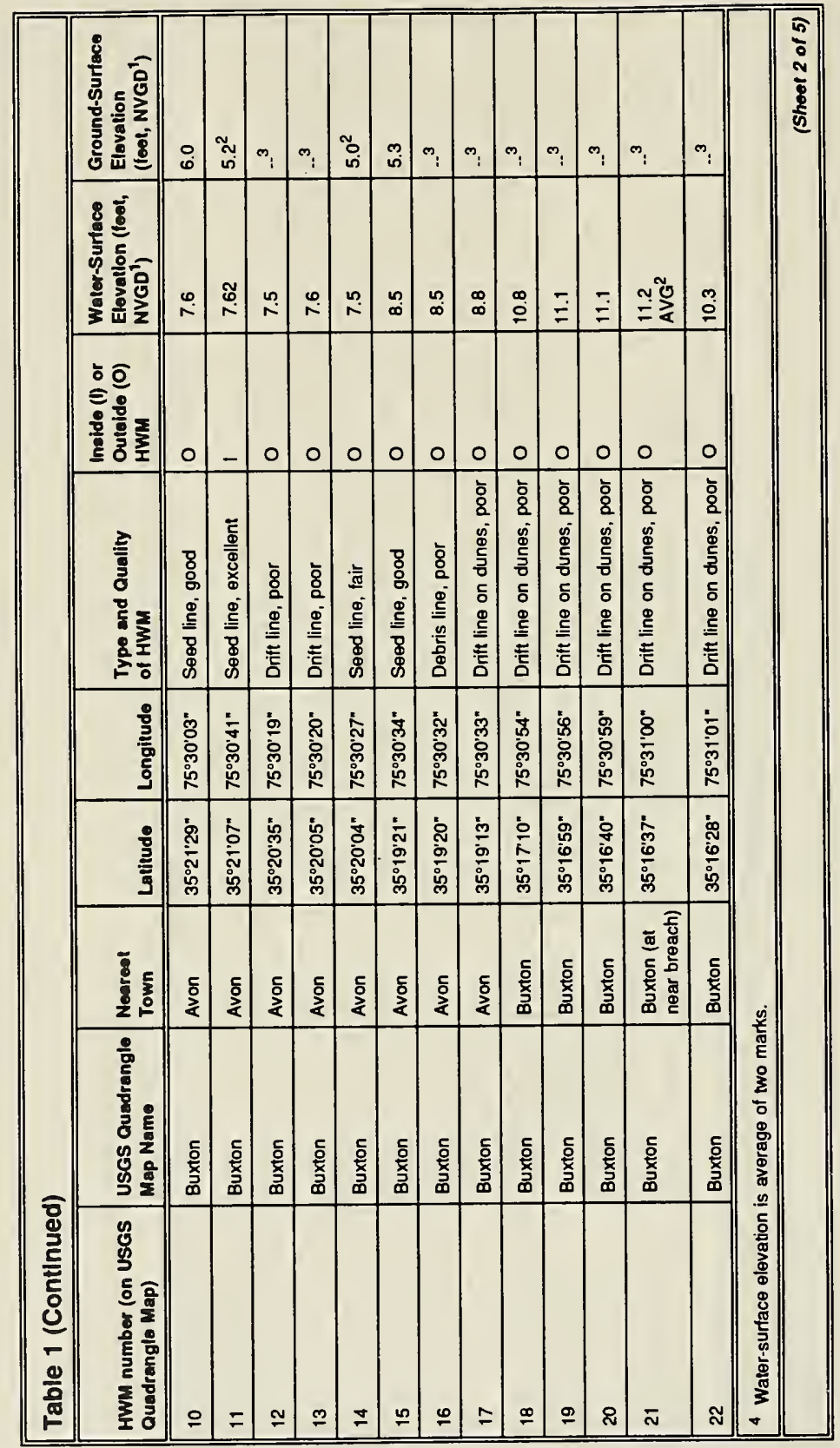




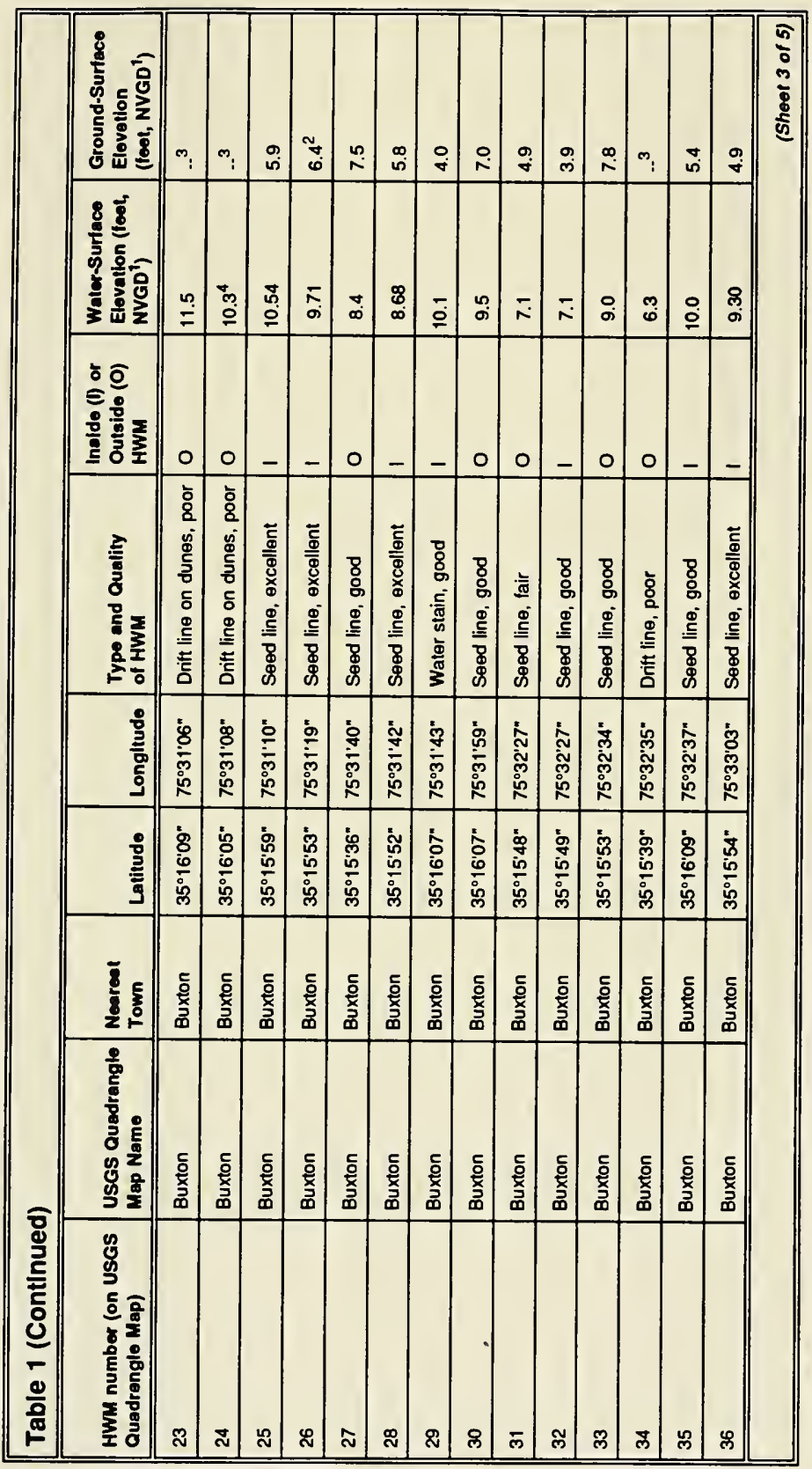




\begin{tabular}{|c|c|c|c|c|c|c|c|c|c|c|c|c|c|c|c|c|}
\hline & 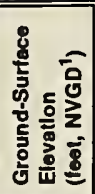 & $\stackrel{\infty}{\dot{\nabla}}$ & $m^{\infty}:$ & $m_{1}$ & ڤ̊ & $\underset{\forall}{\sim}$ & $\begin{array}{l}\stackrel{\oplus}{\sigma} \\
\dot{n}\end{array}$ & $\stackrel{m}{+}$ & $\stackrel{\infty}{\infty}$ & $\stackrel{n}{*}$ & i̊ & i. & $n_{1}$ & ${ }^{\infty}:$ & $m_{1}$ & $\begin{array}{l}\frac{5}{0} \\
\frac{0}{5} \\
\frac{5}{5}\end{array}$ \\
\hline & 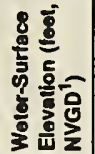 & ণै & 芯 & $\underset{\omega}{\mathscr{\omega}}$ & $\vec{\oplus}$ & $\stackrel{9}{\infty}$ & $\underset{\infty}{\bar{\infty}}$ & $\stackrel{\mathbb{a}}{\sim}$ & $\stackrel{\circ}{\infty}$ & $\begin{array}{l}0 \\
0 \\
\infty\end{array}$ & $\bar{\infty}$ & $\widehat{\infty}$ & $\stackrel{\infty}{\infty}_{\infty}^{\bar{\infty}}$ & $\stackrel{\infty}{\sim}$ & $\hat{N}$ & \\
\hline & 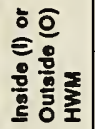 & -1 & 0 & 0 & 0 & - & - & -1 & -1 & - & 0 & - & 0 & 0 & 0 & \\
\hline & 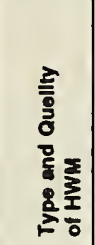 & 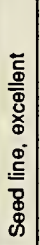 & 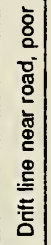 & 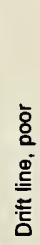 & 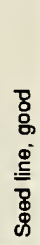 & 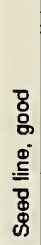 & 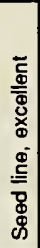 & 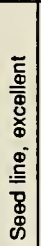 & 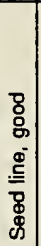 & 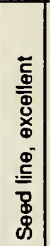 & 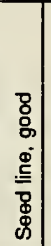 & 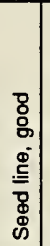 & 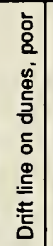 & 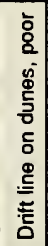 & 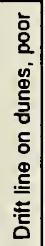 & \\
\hline & 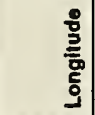 & 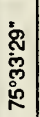 & 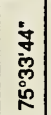 & 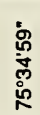 & 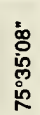 & 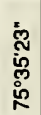 & 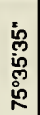 & 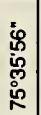 & $\begin{array}{l}\dot{0} \\
\vdots \\
0 \\
0 \\
م\end{array}$ & $\begin{array}{l}: \\
= \\
0 \\
0 \\
0 \\
0\end{array}$ & 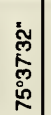 & $\begin{array}{l}: \\
\overline{0} \\
0 \\
0 \\
0\end{array}$ & 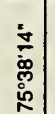 & 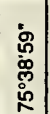 & 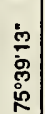 & \\
\hline & $\stackrel{\circ}{\stackrel{ }{3}}$ & 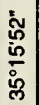 & $\begin{array}{l}\text { के } \\
\text { in } \\
\text { ì } \\
\text { ôn }\end{array}$ & 今ે & స్స్ & 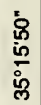 & 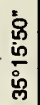 & 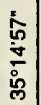 & 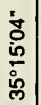 & 疍 & : & 占 & 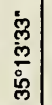 & 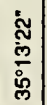 & 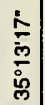 & \\
\hline & $\begin{array}{l}\overline{8} \\
\frac{8}{2} \\
\frac{8}{2}\end{array}$ & 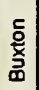 & 总 & $\begin{array}{l}\text { : } \\
\text { 总 } \\
\text { L }\end{array}$ & $\begin{array}{l}\text { : } \\
\text { 总 } \\
\text { L }\end{array}$ & $\begin{array}{l}8 \\
\text { 吕 } \\
\text { 总 }\end{array}$ & 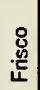 & $\begin{array}{l}8 \\
\text { 吕 } \\
\text { 总 }\end{array}$ & $\begin{array}{l}\stackrel{0}{0} \\
\text { 总 }\end{array}$ & $\begin{array}{l}8 \\
\dot{b} \\
\text { 点 }\end{array}$ & 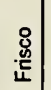 & 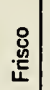 & 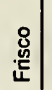 & 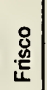 & 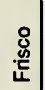 & \\
\hline & 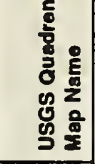 & $\begin{array}{l}\text { ᄃ } \\
\overline{\mathbf{y}} \\
\overline{\mathbf{D}}\end{array}$ & 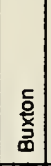 & 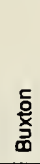 & 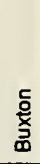 & 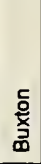 & 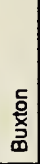 & 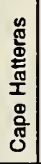 & 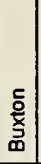 & 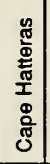 & 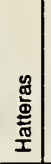 & 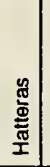 & 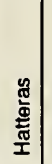 & 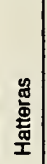 & 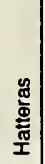 & \\
\hline 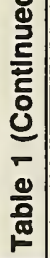 & 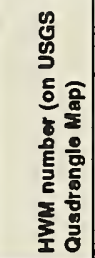 & ले & 罡 & g & 운 & $\overline{7}$ & ฯ & ? & 寸 & $\stackrel{2}{q}$ & $\mathscr{\sigma}$ & F & g & g & 吊 & \\
\hline
\end{tabular}




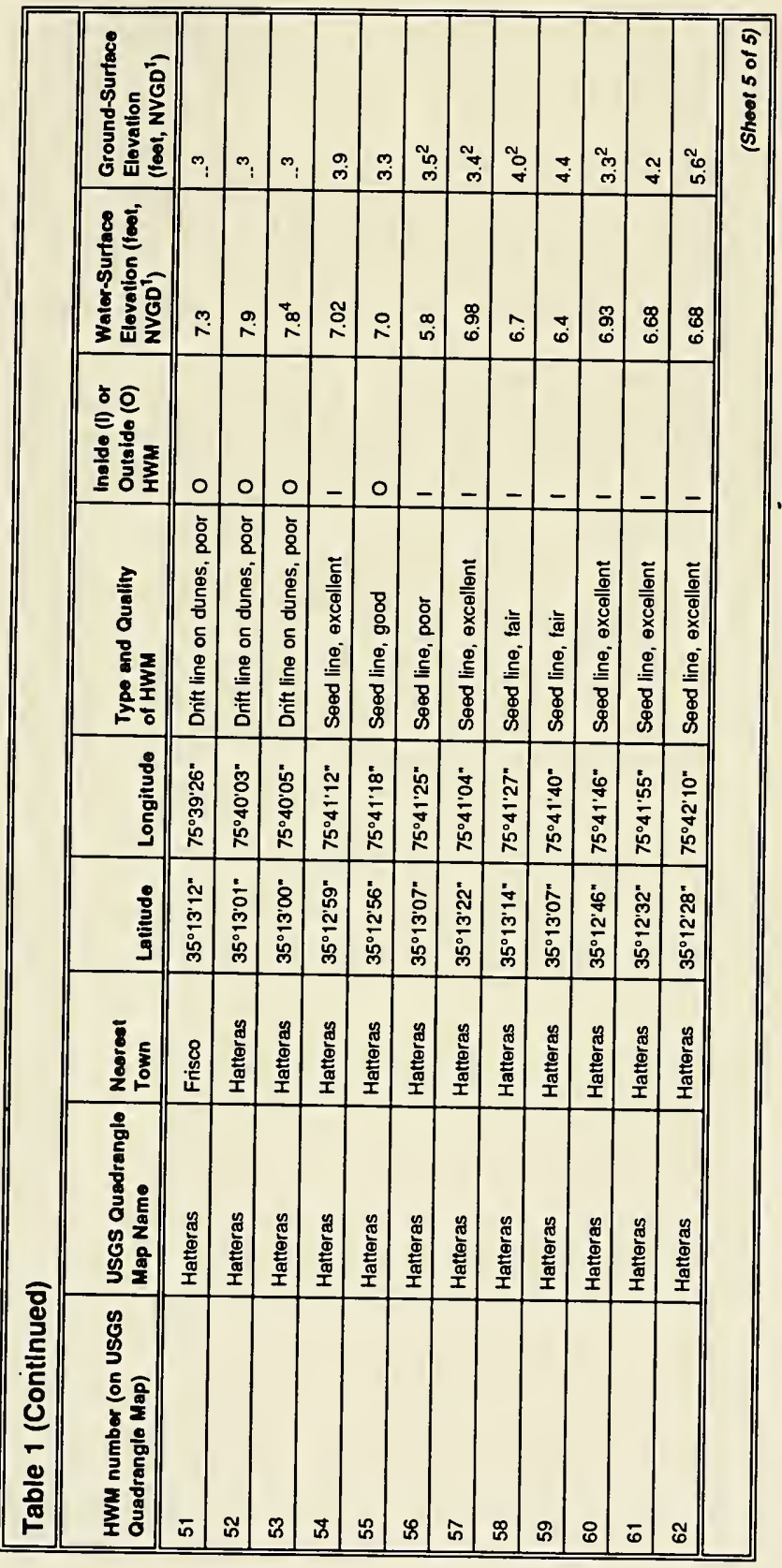


the community of Buxton, where the orientation of Cape Hatteras transitions from predominantly north-south to east-west. Four high-water marks exceeding $11 \mathrm{ft}$ NGVD were recovered just east of Buxton.

The zone of highest water levels on the Outer Banks due to Emily was near the community of Buxton, most of which was inundated. Water levels in Buxton ranged from about 7 to $10 \mathrm{ft}$, with flooding coming from Pamlico Sound. The area south of Buxton, Buxton Woods, is densely vegetated, making recovery of high-water marks difficult. While no definitive high-water marks were recovered in this area, there were indications of saltwater intrusion.

To the west of Buxton, the village of Frisco was inundated, with high-water marks at elevations between 8 and $9 \mathrm{ft}$. Hatteras, the west-most community on Hatteras Island, also was completely inundated with high-water marks at elevations between 6 and $7 \mathrm{ft}$. As at the community of Buxton, flooding came from Pamlico Sound. 


\section{Summary}

Figure 7 illustrates storm-induced flooding. Zones of water elevations in feet above NGVD are denoted. The figure is intended as a general overview; therefore, isolated high-water marks of unusually high or low elevations within a given zone have been ignored in the preparation. Based upon the recovered high-water marks, all of the flooding on the Outer Banks appears to have come from the Pamlico Sound side of the barrier island. This interpretation is based upon the gradient of elevations of high-water marks which slopes from the Sound to the ocean and is consistent with the streamline patterns depicted in the wind analyses of Chapter 3. The streamlines indicating wind direction in the $2200 \mathrm{hr}$ UTC analysis (Figure 5), the time of PCA, are most shore-normal along the east-west-oriented reach of Cape Hatteras. The isotachs indicating the most intense wind speeds over land, approximately 90 knots, are located near Buxton, where the highest water levels occurred.

Hurricane Emily was unusual in that it caused significant flooding and damage on the Outer Banks, yet never made landfall in the commonly accepted sense because the eye of the storm stayed over water. Emily was also unusual in causing the most pronounced flooding along the back side of a barrier island system. 


\section{References}

Burpee, R. W., Aberson, S. D., Black, P. G., DeMaria, M., Franklin, J. L., Griffin, J. S., Houston, S. H., Kaplan, J., Lord, S. J., Marks, F. D., Jr., Powell, M. D., and Willoughby, H. E. (1994). "Real-time guidance provided by NOAA's hurricane research division to forecasters during Hurricane Emily of 1993," Bull. Amer. Met. Soc. 75, 1765-83.

Lawrence, M. (1993). "Preliminary report, Hurricane Emily; 22 August 06 September 1993," unpublished manuscript, National Hurricane Center, National Oceanic and Atmospheric Administration.

Powell, M. D., Dodge, P. P., and Black, M. L. (1993). "The landfall of Hurricane Hugo in the Carolinas: Surface wind distribution," Weather and Forecasting. 6, 379-99.

Powell, M. D., Houston, S. H., and Reinhold, T. A. (1995). "Hurricane Andrew's landfall in south Florida; Part I: Standardizing measurements for documentation of surface wind fields," Weather and Forecasting, in press. 


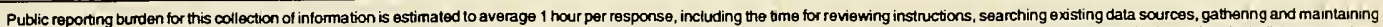

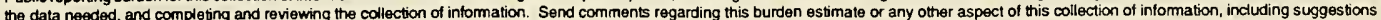

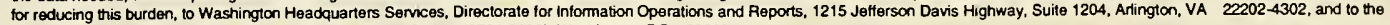
Otfice of Management and Budget, Paperwork Peduction Project (0704-0188), Washington, DC 20503.
1. AGENCY USE ONLY (Leave blank)
2. REPORT DATE
December 1995
3. REPORT TYPE AND DATES COVERED
Final report

4. TITLE AND SUBTITLE

Surface Wind Analyses and Storm-Surge Effects of

Hurricane Emily on the Outer Banks of North Carolina

6. AUTHOR(S)

Andrew W. Garcia

5. FUNDING NUMBERS

7. PERFORMING ORGANIZATION NAME(S) AND ADDRESS(ES)

U.S. Army Engineer Waterways Experiment Station

3909 Halls Ferry Road, Vicksburg, MS 39180-6199

8. PERFORMING ORGANIZATION REPORT NUMBER

Miscellaneous Paper CERC-95-9

9. SPONSORINGMONITORING AGENCY NAME(S) AND ADDRESS(ES)

Headquarters, U.S. Army Corps of Engineers

10. SPONSORING/MONITORING

AGENCY REPORT NUMBER

Washington, DC 20310-1000

11. SUPPLEMENTARY NOTES

Available from National Technical Information Service, 5285 Port Royal Road, Springfield, VA 22161.

12a. DISTRIBUTIONAVAILABILTTY STATEMENT

Approved for public release; distribution is unlimited.

12b. DISTRIBUTION CODE

\section{ABSTRACT (Maximum 200 words)}

Surface meteorological and coastal storm-surge data for Hurricane Emily (22 August - 6 September 1993) are presented. These data include maximum surface wind speed and minimum surface central pressure histories, surface wind analyses at times of Emily's closest approach to land, $8 \mathrm{hr}$ prior, and $4 \mathrm{hr}$ following; and storm surge data in both tabular and graphic form for the Outer Banks of North Carolina. The report documents Emily's effects in the primary area of impact. Emily's coastal effects are noteworthy in that inundation of the barrier island system was due to high waters from Pamlico Sound rather than the Atlantic Ocean.

\section{SUBJECT TERMS}

Hurricane effects

Hurricane Emily

Hurricane winds

Storm surge

17. SECUAITY CLASSIFCATION OF REPORT

UNCLASSIFIED
18. SECURITY CLASSIFICATION OF THIS PAGE UNCLASSIFIED
15. NUMBER OF PAGES

24

16. PRICE CODE 

Destroy this report when no longer needed. Do not return it to the originator. 

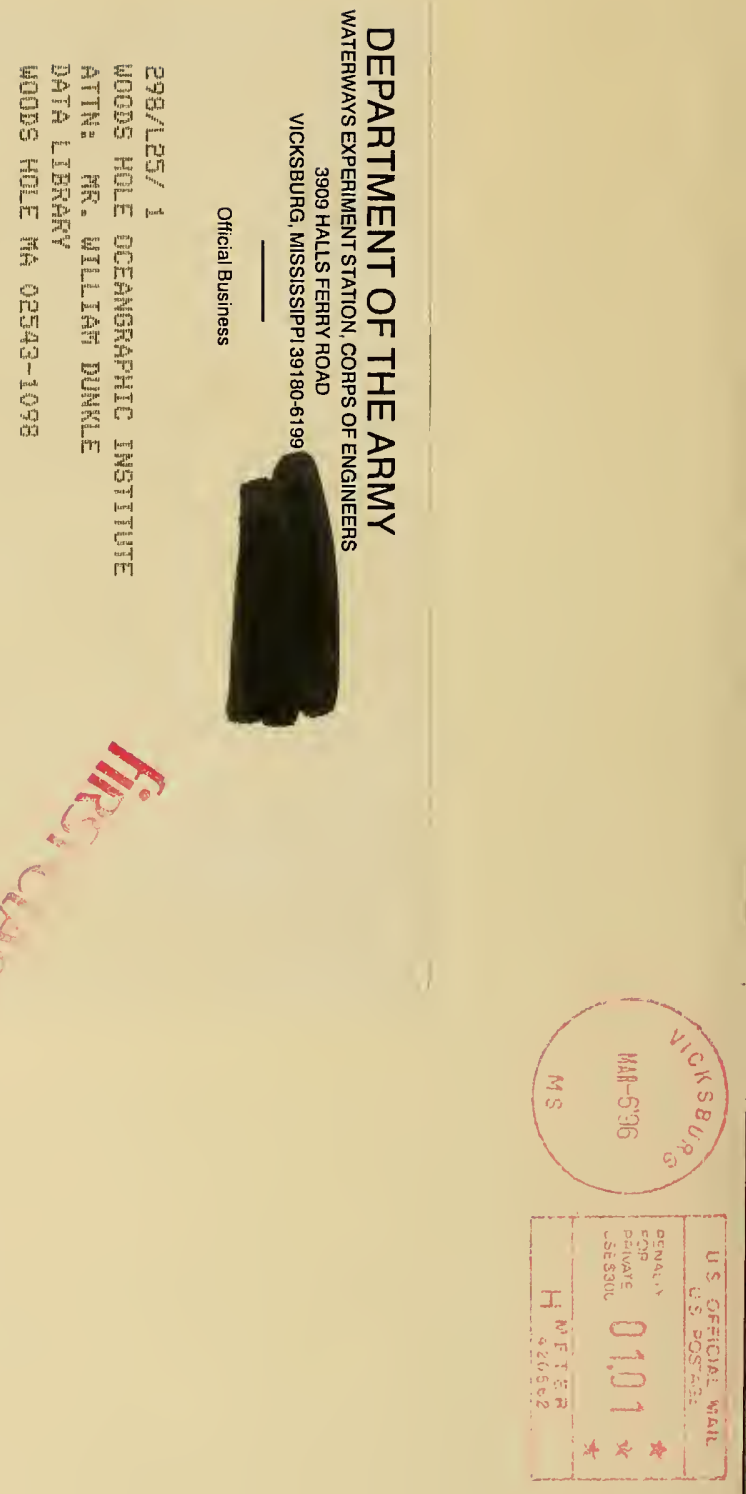